\title{
An Ecosystem-Based Research Program for Capelin (Mallotus villosus) in the Northwest Atlantic: Overview and Results
}

\author{
G. K. Davoren, C. May, P. Penton and B. Reinfort \\ Department of Zoology, University of Manitoba, \\ Winnipeg, MB, R3T 2N2, Canada \\ E-mail: davoreng@cc.umanitoba.ca
}

A. Buren, C. Burke, D. Andrews and W. A. Montevecchi

Cognitive and Behavioural Ecology Programme,

Departments of Psychology, Memorial University of Newfoundland,

St. John's, NL, A1B 3X9, Canada

\author{
N. Record and B. deYoung \\ Department of Physics and Physical Oceanography, \\ Memorial University of Newfoundland, \\ St. John's, NL, A1B 3X9, Canada
}

\section{Rose-Taylor and T. Bell}

Department of Geography, Memorial University of Newfoundland, St. John's, NL, A1B 3X9, Canada

\author{
J.T. Anderson and M. Koen-Alonso \\ Northwest Atlantic Fisheries Centre, Fisheries and Oceans Canada, \\ P.O. Box 5667, St. John's, NL, A1C 5X1 Canada
}

\author{
S. Garthe \\ Research and Technology Centre, University of Kiel, \\ Hafentörn 1, D-25761 Büsum, Germany
}

Davoren, G. K., C. May, P. Penton, B. Reinfort, A. Buren, C. Burke, D. Andrews, W. A. Montevecchi, N. Record, B. deYoung, C. Rose-Taylor, T. Bell, J.T. Anderson, M. Koen-Alonso, and S. Garthe. An Ecosystem-Based Research Program For Capelin (Mallotus villosus) in the Northwest Atlantic: Overview and Results. J. Northw. Atl. Fish. Sci., 39: 35-48. doi:10.2960/J.v39.m595

\begin{abstract}
The Northwest Atlantic has been undergoing extensive ecosystem shifts involving oceanographic change and over-fishing. Capelin (Mallotus villosus), the focal forage fish species in this system, is a primary prey for most large predators, including cod, seals, whales and seabirds. Recently, the biology and behaviour of capelin has changed dramatically, although the basis for these changes is not well understood. Through a collaborative, multi-disciplinary research program among university, government and commercial fishers, we investigated mechanisms underlying these changes. In this manuscript we present an integrated overview of this initiative and synthesize key results from research carried out within the program. Our meso-scale study area encompassed the Funk Island Seabird Ecological Reserve, situated $60 \mathrm{~km}$ northeast of the Newfoundland coast. We identified 11 off-beach demersal spawning sites of capelin, which were primarily associated with small gravel in bathymetric depressions where temperatures were $>2{ }^{\circ} \mathrm{C}$. Through comparisons of beach and demersal spawning, we described two distinct developmental strategies of eggs: high mortality and rapid development for beach sites versus low mortality and slow development for demersal sites. Emergence strategies of larvae at demersal sites also differed from beach sites elsewhere in Newfoundland. Integrating results from vessel-based and moored hydroacoustics (Acoustic Doppler Current Profilers) and biological sampling suggested that the diel vertical migratory patterns of capelin and its zooplankton prey are related. Capelin $>120 \mathrm{~mm}$ total length migrated with larger, longer-distance (0-300 m) crustacean migrators (amphipods, euphausiids), whereas capelin $<120 \mathrm{~mm}$ migrated with smaller, shorter-distance $(0-100 \mathrm{~m})$ migrators (copepods). These patterns influenced the diurnal feeding patterns of top predators. Vessel-based measures of observed seabird distributional patterns and trawl-estimated capelin availability and colony-based measures of seabird diets
\end{abstract}


revealed that seabirds are selective in their pursuit of forage prey and that they expand their foraging ranges considerably when capelin were less available in certain years. Furthermore, changes in the dietary composition of common murre (Uria alge) can be linked to changes in the availability of capelin $>100 \mathrm{~mm}$, suggesting that the diet of common murre, and perhaps of other seabirds, has the potential for becoming a quantitative indicator of capelin status. Overall, this type of research framework will be important for moving toward ecosystem-based management approaches.

Key words: capelin, demersal and beach spawning, diel vertical migration, modeling, Northwest Atlantic, predator-prey interactions, seabirds, zooplankton

\section{Introduction}

There is an urgent need for improved conservation of marine ecosystems. Almost $50 \%$ of all world fish stocks are considered fully-fished, nearly $30 \%$ are considered over-fished, depleted or recovering from a collapse, and the trend towards over-fishing continues (Garcia and Leiva-Moreno, 2003). Collapses of fisheries are a global concern (Pauly et al., 2002) and over-exploited species require considerable time to recover (Hutchings, 2000). Fisheries impacts reach beyond target species (Yodzis, 1994; Bianchi et al., 2000) and can cause ecosystems to shift to alternate stable-states (Petraitis and Dudgeon, 2004; Frank et al., 2005). The problems with single species management and the recognition of the complexity of marine ecosystem interactions have led to a broad movement towards ecosystem-based approaches in fisheries management (FAO, 2003). From a fisheries science perspective, this shift in approach implies moving from population to community ecology as the basis for the assessment and advice (Mangel and Levin, 2005). Understanding ecosystem function, therefore, becomes a central element for ensuring a sustainable use of marine resources.

In marine ecosystems, top-down control (control by predators, including fisheries), bottom-up control (control by primary producers) and wasp-waist control (control by numerically abundant species, usually forage fish species) are three conceptual schemes commonly used to describe the mechanisms that regulate energy flow (Cury et al., 2003). The type of control(s) and the precise nature of the mechanism(s) involved will determine the system dynamics and its responses to perturbation, either human- or environmentally-driven.

The Northwest Atlantic marine community can be described as a wasp-waist system where capelin (Mallotus villosus) lies at the core of its food web (Rice, 1995; Bakun, 2006). Capelin provide essential linkages for energy transfer among trophic levels (Lavigne, 1996). This system is currently undergoing shifts in pelagic and demersal food webs (e.g. Montevecchi and
Myers, 1996, 1997; Carscadden et al., 2002; Davoren and Montevecchi, 2003a), including a drastic reduction of large predatory fishes like Atlantic cod Gadus morhua (Hutchings and Myers, 1994; Myers et al., 1997) and a fluctuating ocean climate (Drinkwater, MS 1996, 2002). Major changes in the biology, behaviour and distribution of capelin, the dominant forage fish species, have also been documented (Carscadden and Nakashima, MS 1997). Changes include delayed and protracted spawning, which may be associated with a higher occupation of deep water or demersal spawning sites (Nakashima and Wheeler, 2002), reduced size and age at maturity, and reduced somatic condition (Carscadden and Frank, 2002). In addition, shifts in horizontal and vertical distributional patterns have been observed, which may be associated with changes in availability of zooplankton prey (Mowbray, 2002). Because top vertebrate predators, including marine birds, mammals and large predatory fish, rely on capelin for food (Lilly 1991, Montevecchi, 2000; Carscadden et al., 2002), significant impacts of these changes have been recognized at higher trophic levels, including declining condition of cod (Rose and O'Driscoll, 2002) and seabird chicks (Davoren and Montevecchi, 2003a).

In this context, we developed a collaborative multidisciplinary program to investigate mechanisms underlying recent changes in capelin behaviour and biology in the Northwest Atlantic and their potential impacts on top vertebrate predators using an ecosystem approach. We studied three aspects of capelin behaviour and biology, including (1) the relative contribution of demersal and beach spawning to recruitment in Newfoundland; (2) the bio-physical factors underlying vertical movement patterns of capelin in the water column by examining species interactions among zooplankton, capelin and seabirds; and (3) the influence of capelin availability on the foraging and breeding activities of seabird predators of different body sizes that use varying provisioning strategies. The objective of this paper is to provide an integrated overview of the program itself and some of the key findings of the research. In presenting these results in an integrated fashion, we highlight the ecosystem-scope of 
this initiative and emphasize the importance of research programs that incorporate multiple ecosystem components, scientific disciplines, and research institutions.

\section{Materials and Methods}

\section{Study Area and Research Design}

Research was addressed at both fine- (1-10 km) and meso-scale levels $(10-1000 \mathrm{~km})$ in the area surrounding the Funk Island Seabird Ecological Reserve during the capelin reproductive season (Fig. 1). Funk Island is the site of the largest colony of common murres Uria aalge in the world, the fourth largest and most oceanic northern gannet (Sula bassana) colony in North America, and the former site of the largest known colony of the now extinct great auk (Penguinis immpennis) (Montevecchi and Tuck, MS 1987). Biological hotspots, or areas of high abundances of different species, are concentrated in this area (Davoren, 2007), making this an excellent locale for ecosystem-based research.

To investigate the relative contribution of demersal and beach spawning to capelin recruitment, fieldwork was conducted on beaches and from the commercial
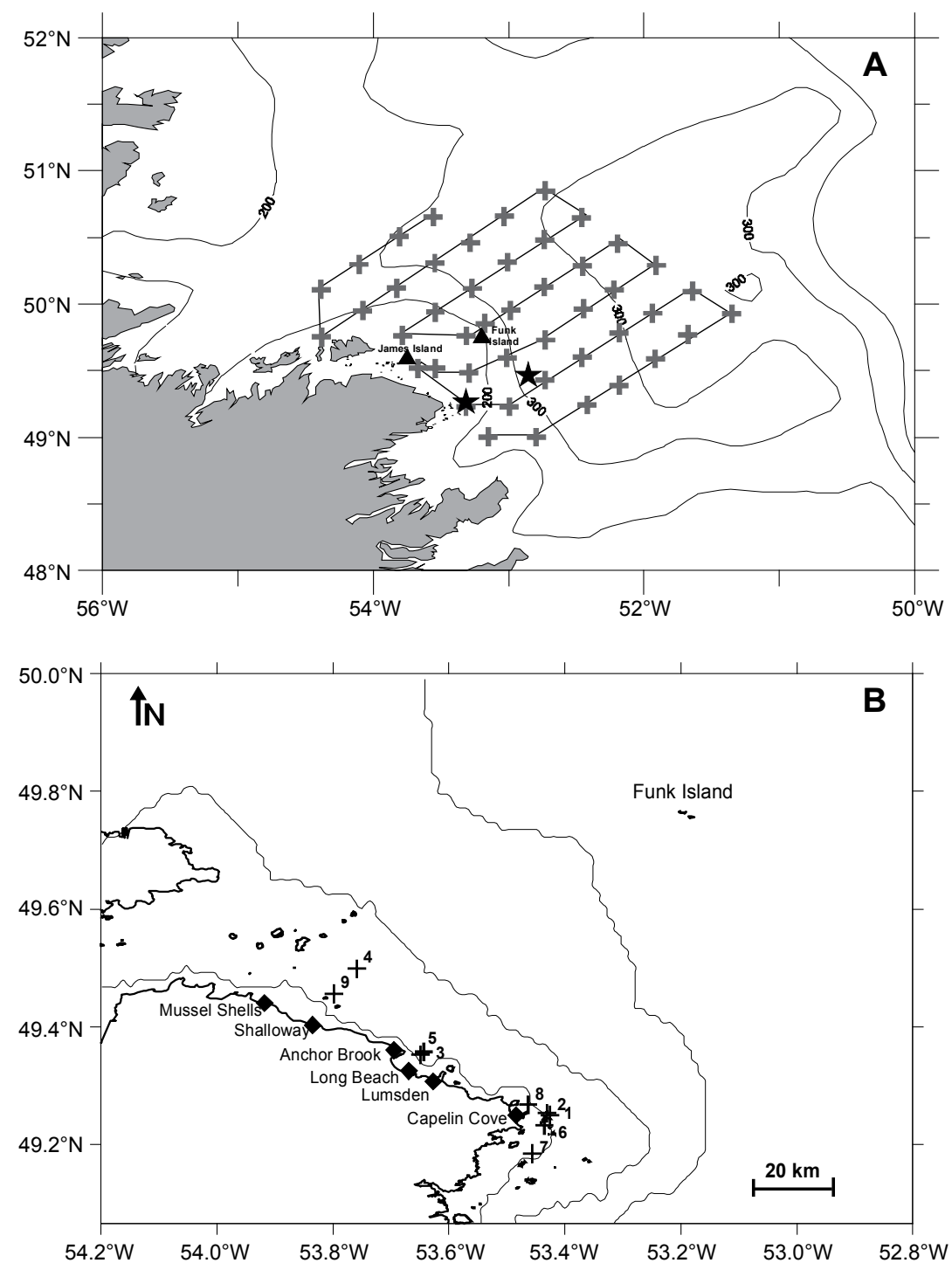

Fig. 1. Map of the study area showing (A) the meso-scale acoustic survey track (solid line), International Young Gadoid Pelagic Trawl (IGYPT) stations (crosses), oceanographic mooring sites (stars) and seabird colonies (triangles); and (B) the location of beach (diamonds) and demersal (crosses) spawning sites discovered from 2003-2005. 
fishing vessel FV Lady Easton II, during June-August of 2004-2006. To investigate the influence of capelin availability on seabird predators, a meso-scale survey $\left(49^{\circ} 00^{\prime} \mathrm{N}-51^{\circ} 00^{\prime} \mathrm{N}, 53^{\circ} 00^{\prime} \mathrm{W}-55^{\circ} 00^{\prime} \mathrm{W}\right)$ was conducted in August of 2004-2006 from the Canadian Coast Guard Ship Wilfred Templeman simultaneously with colony-based research on seabird diet and provisioning strategies at Funk Island. The survey was centered on Funk Island and designed to encompass the maximum foraging ranges of the seabirds breeding on the island. During the vessel-based survey, we continuously recorded hydroacoustic data simultaneous with counts of marine birds and mammals using standardized strip transect methods (Tasker et al., 1984). The survey was periodically interrupted at pre-determined stations to examine the thermo-haline properties of the water column and the species composition of acoustic signals by sampling with nets of different mesh size. At each station, a SeaBird 25 was deployed $(0-100 \mathrm{~m})$, along with bongo nets (232 and $333 \mu \mathrm{m}$ graded mesh) from $0-100 \mathrm{~m}$ and an International Young Gadoid Pelagic Trawl (IYGPT) from 20-60 m (Anderson and Dalley, 1997). Experimental work within fine-scale areas $(1-10 \mathrm{~km})$ were also conducted aboard the CCGS Wilfred Templeman in August of 2004-2005 to determine the mechanisms influencing the vertical distribution of capelin in the water column.

\section{Capelin Spawning}

To compare egg densities along with developmental and survival rates of eggs between beach and demersal spawning locations, we collected egg-bearing gravel at the beach ( $n=1-2$ sites) using a $6.5 \mathrm{~cm}^{2}$ internal diameter steel corer and at demersal sites ( $n=5-8$ sites) using a $30 \mathrm{~cm}^{2}$ Van Veen bottom grab system in 2004 and 2005. Samples were collected at 2-3 d intervals and a random sample of 50 eggs from each sample was examined to determine the proportion of eggs in each developmental stage, based on a modification of Fridgeirsson's (1976) description of capelin egg development (Frank and Leggett, 1981b). A central measure of egg development was calculated for each day using the following equation:

$$
\bar{s}=\sum_{i=1}^{6} s_{i} e_{i} / \sum_{i=1}^{6} e_{i}
$$

where $\bar{s}$ is the weighted mean developmental stage index (WMDSI), $s_{i}$ is the developmental stage index, and $e_{i}$ is the average proportion of eggs in each developmental stage (Frank and Leggett, 1981b). Time to hatch was estimated by extrapolating WMDSI plots to stage VII (hatching). To determine whether environmental cues triggered larval emergence from sediments, as shown for other beach (Frank and Leggett, 1981a, Leggett et al.,
1984) and demersal sites (Carscadden et al., 1989) in Newfoundland, we collected larvae at beach and demersal sites. Larvae were collected at demersal sites during the post-hatch period by towing a $270 \mu \mathrm{m}$ mesh larval net in the top 5-10 $\mathrm{m}$ of the water column. Larvae were collected at beach sites by towing a $165 \mu \mathrm{m}$ mesh larval net for $40 \mathrm{~m}$ in $<1 \mathrm{~m}$ of water parallel to the area of egg deposition. Vemco Miniloggers (Vemco 8-bit MinilogTR) were anchored near the seabed at demersal spawning sites and within each tidal zone at beach sites to characterize hourly temperatures experienced by incubating eggs and larvae prior to emergence from the sediment. Temperature profiles of the water column were measured using a Conductivity-Temperature-Depth Profiler (SeaBird 19) on each sampling day in 2004 to characterize the thermal properties of the water column in relation to thermistor data. Hourly wind speed and direction were obtained from daily summaries published by Environment Canada for the local meteorological station at Pool's Island, $13.5 \mathrm{~km}$ southeast of the spawning sites (Davoren et al., 2006).

We ran acoustic surveys over seven demersal spawning sites, as well as one similar non-spawning location, to see if demersal spawning sites can be delineated based on acoustic signatures. Surveys were run either in a star pattern or as a series of east-west and north-south parallel lines for 1-2 km areas centered over the sites and the non-spawning location. A normal incidence $120 \mathrm{kHz}$ dual beam system (BioSonics DT-X, BioSonics Inc., Seattle, Washington) was used to ensonify the seabed at 1 $\mathrm{Hz}$ and $0.4 \mathrm{~ms}$ pulse width. The transducer was housed in a hydrodynamic V-fin towed at speeds of 5-6 knots (2.6$3.1 \mathrm{~ms}^{-1}$ ) approximately $5 \mathrm{~m}$ below the ocean surface off the starboard side of the ship. To ground-truth acoustic data, sediment samples were collected using a $30 \mathrm{~cm}^{2}$ Van Veen bottom grab system and video images were taken throughout the acoustically surveyed areas using a small remotely operated vehicle (VideoRay Pro). The first echo from the seabed for the wide beam (12 degrees at $3 \mathrm{~dB}$ half power level) was analyzed using QTC IMPACT (QTC, 2004). Five acoustic pings were stacked to generate a single normalized echo envelope to increase the signal to noise ratio. Unsupervised classifications of the acoustic data were conducted for each of the eight data sets. The number of unsupervised classes was determined by the lowest total score of the three axes based on k-means partitioning using an iterative process (Freitas et al., 2003; Preston and Kirlin, 2003).

\section{Diel Vertical Migration}

To examine the role of diel vertical migrations (DVM) of zooplankton in shaping the migratory patterns of capelin, we described DVM patterns of zooplankton 
and post-spawning capelin. In 2004, a stationary mooring with two $300 \mathrm{kHz}$ broadband Acoustic Doppler Current Profilers (ADCPs) was deployed at a point location within the study area $\left(49^{\circ} 27.85^{\prime} \mathrm{N}, 52^{\circ} 51.30^{\prime} \mathrm{W}\right.$, depth $327 \mathrm{~m}$; Fig. 1) for $14 \mathrm{~d}$ to continuously record zooplankton DVM. Thermistors $(n=20)$ were attached at regular depth intervals to record the thermal properties of the water column at $10 \mathrm{~min}$ intervals. These data were used in conjunction with cloud cover data, and historical ADCP data from 11 moorings on the Newfoundland Shelf to examine the external factors that influence zooplankton migration (Record and deYoung, 2006). Similarly in 2005 , one stationary mooring was deployed within the study area $\left(49^{\circ} 33.3^{\prime} \mathrm{N}, 52^{\circ} 50.0^{\prime} \mathrm{W}\right.$, depth $\left.385 \mathrm{~m}\right)$ for 19 d. Similar to 2004 , the mooring was configured with thermistors at regular depth intervals and two ADCPs, which collected acoustic data within two discrete depth ranges $(0-100 \mathrm{~m}$ and $200-320 \mathrm{~m})$.

To examine the DVM of capelin, we conducted a $4 \mathrm{~d}$ fine-scale study (9-13 August 2005) centered on the area where a large concentration of post-spawning capelin was identified during the meso-scale survey in 2004 $\left(49^{\circ} 49^{\prime} \mathrm{N}, 52^{\circ} 57^{\prime} \mathrm{W}\right.$ to $\left.49^{\circ} 18^{\prime} \mathrm{N}, 53^{\circ} 04^{\prime} \mathrm{W}\right)$, which also was near the oceanographic mooring. To determine the species composition of the ADCP acoustic signals of zooplankton, we conducted daylight and dark plankton tows (Bongo net: $232 \mu \mathrm{m}$ mesh; Tucker trawl: 1000 , 570 and $333 \mu \mathrm{m}$ graded mesh) to 50,100 and $220 \mathrm{~m}$. The following data were collected repeatedly, such that all $2 \mathrm{~h}$ blocks over the $24 \mathrm{~h}$ cycle were sampled at least once during the $4 \mathrm{~d}$ study. A Sea-Bird 25 with a Licor Par sensor was deployed repeatedly to measure temperature and light profiles of the water column. To quantify the migratory patterns of capelin, we repeatedly collected hydroacoustic data (Simrad EK500, $38 \mathrm{kHz}$ split-beam transducer) along a radial survey $(\sim 30 \mathrm{~km})$ over the main concentration of capelin. Targeted tows (IYGPT) were conducted repeatedly to sample capelin and stomachs were removed for later determination of stomach fullness and species composition.

To investigate whether foraging patterns of common murres and northern gannets were influenced by the DVM of capelin, we analyzed data collected previously on the foraging activities and diets of seabirds rearing chicks at Funk Island (Davoren and Montevecchi, 2003a; Garthe et al., 2003). Foraging activities were measured both indirectly, through full-day observations of parental prey deliveries to murre chicks in 1998 ( $n=22$ nests) and $1999(n=32$ nests; Davoren and Montevecchi, 2003b), and directly, through bird-borne temperature-depth recorders (TDRs) on gannets in 1999
( $n=11$ individuals) and $2003(n=11$ individuals; Garthe et al., 2003, 2007).

\section{Seabird Diets and Capelin Availability}

We focused on two closely related seabird predators with different foraging strategies, the Atlantic puffin (Fratercula arctica), a dietary generalist that is a multiple prey loader, and the common murre, a dietary specialist that is a single prey loader and the primary seabird consumer of capelin in the Northwest Atlantic (Montevecchi, 2000). We described the composition of prey types and sizes in parental prey loads of murres (\% number) and puffins (\% frequency) at Funk Island and described the dietary overlap between the two species using Petraitis (1979) General Overlap index. Common murres rarely deliver fish smaller than $100 \mathrm{~mm}$ total length ${ }^{1}$ to their chicks (Birkhead and Nettleship, 1987; Barrett, 2002; Davoren and Montevecchi, 2003a), and we therefore defined capelin larger than $100 \mathrm{~mm}$ as 'suitable capelin' and use the term from this point forward to describe common murre's parental deliveries. We defined three prey categories for murre diets: small capelin (100-140 mm), large capelin (>140 mm) and other prey (every prey type other than capelin). The classification of 'suitable capelin', however, is not appropriate for puffins as they deliver capelin larger and smaller than $100 \mathrm{~mm}$ to their chicks. Therefore, prey categories in puffin prey loads are classified as sandlance, capelin $>100 \mathrm{~mm}$ and "goop" which refers to prey loads containing numbers of larval and young of the year demersal fish and shrimp.

We characterized the prey field using information collected from the IYGPT during the meso-scale survey in August of 2004 and 2005. Estimates of the distance that murres and puffins traveled from the colony to foraging areas were derived from observations of birds at sea. The masses and wing chord lengths of murre and puffin chicks were measured and offspring performance was gauged using a 'developmental condition index' (Bertram et al. 2002) that compares individual body mass $(\mathrm{g})$ in relation to wing length $(\mathrm{mm})$ using an analysis of covariance (ANCOVA). The ANCOVA tests for differences in body mass between years while holding wing length constant.

To gain insight into how seabirds cope with changes in prey availability, we assessed diet choices, prey preferences and distances traveled from the colony in light of known forage fish availability in 2004 and 2005. To build predictive capacity of a predator's response to the dynamics of its prey, we modeled the functional relationship between prey availability and the dietary composition of common murres (as inferred from the parental

\footnotetext{
All fish measurements in this paper refer to total length.
} 
prey deliveries). For this modeling exercise, we used data gathered in the context of this project (2004-2005) combined with archived seabird diet (Davoren and Montevecchi, 2003a) and capelin abundance and distribution data (1995-1999, Anderson et al., 2002). We developed two models, dubbed "statistical" and "ecological", which described the dietary composition of common murres as a function of prey availability. Both models shared the following features: a) each individual parental delivery was considered a single realization from a multinomial probability distribution, and b) the modeling exercise involved estimating the probability of consuming a given prey category as a function of availability (Buren et al., MS 2006). The "statistical" model estimated the probability using a standard multi-category logit model (Agresti, 2002), and the "ecological" model derived the formulation for the probability from functional response theory (Buren et al., MS 2006). These models were compared using the difference between their Akaike Information Criterions corrected for sample size, $\triangle \mathrm{AICc}$ (Burnham and Anderson, 2002).

\section{Results}

\section{Spawning Biology of Beach and Demersal Capelin}

We discovered six spawning beaches and 11 demersal spawning sites at varying depths $(18-33 \mathrm{~m})$ and distances from shore $(2.5-17.7 \mathrm{~km})$ on the exposed northeast Newfoundland coast $\left(49^{\circ} 11^{\prime} \mathrm{N}, 53^{\circ} 27^{\prime} \mathrm{W}\right.$ to $49^{\circ} 27^{\prime} \mathrm{N}, 53^{\circ}$ 47' W) during July-August of 2004-2005 (Fig. 1). The total annual egg deposition per standard core estimate

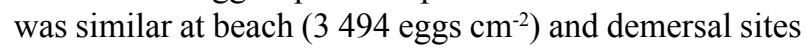
(2 901 eggs $\mathrm{cm}^{-2}$ ) in 2004, but was higher at demersal $\left(1484 \mathrm{eggs} \mathrm{cm}^{-2}\right)$ relative to beach sites $\left(22 \mathrm{eggs} \mathrm{cm}^{-2}\right)$ in 2005. In both years, beach and demersal spawning were spatially and temporally separated, with beach spawning being 10-17 d earlier and shorter in duration (2-4 d) than demersal spawning (8-12 d). This resulted in higher and more variable incubation temperatures at beach relative to demersal sites, with 2005 being significantly warmer than $2004\left(F_{1,114}=46.4, P<0.0001\right)$. Demersal spawning occurred when beach temperatures were still suitable for spawning. Developmental rates of eggs were higher at beach compared to demersal sites in both years (Fig. 2) and egg mortality, or the mean daily proportion of dead eggs, was higher at the beach relative to the demersal sites $\left(F_{1,90}=78.82, P<0.0001\right)$. Overall, we characterized two distinct developmental strategies of eggs: high mortality and rapid development for beach sites versus low mortality and slow development for demersal sites.

Wind events that were oriented towards the coast line $\left(270-0^{\circ}\right)$ correlated with increasing bot-

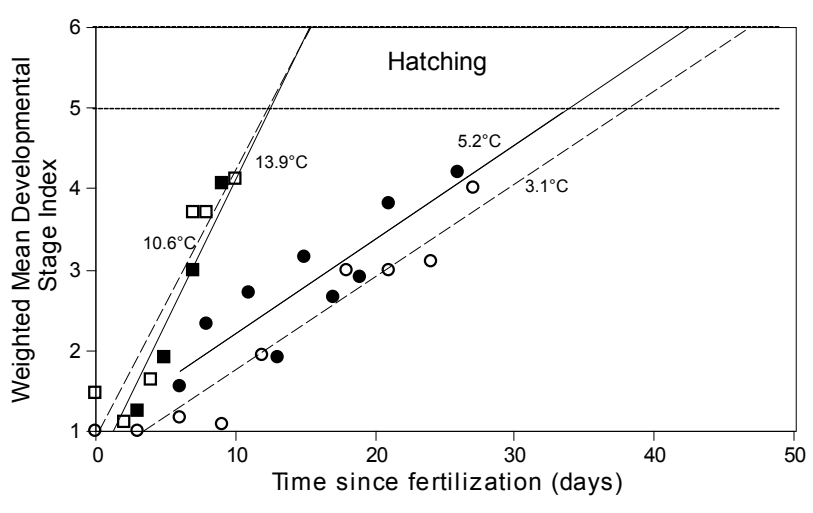

Fig. 2. Capelin egg development rate as determined by the weighted mean developmental stage index at beach ( $\square$ ) and demersal sites (०) in 2004 (open symbol, dotted line) and 2005 (closed symbol, solid line) on the northeast Newfoundland coast. Average incubation temperature is indicated. The dotted horizontal lines indicate the hatching interval.

tom temperature at demersal sites at a time lag of 19-26 $\mathrm{h}$ throughout the post-hatch period (2004: time lag $19 \mathrm{~h}, y=0.0843 x+11.019, r^{2}=0.31, P<0.0001 ; 2005$ : time lag $26 \mathrm{~h}, y=0.0332 x+12.326, r^{2}=0.11, P<0.0001$; Fig. 3).

These short but sharp increases in bottom temperature resulted from the mixing of the stratified water column. Although this increase in temperature is consistent with environmental cues shown to trigger the synchronous emergence of capelin larvae at beach spawning sites (Leggett et al., 1984), there was no relationship between bottom temperature and larval densities at demersal sites $(P>0.05)$. Peaks in recently hatched larvae $(3-5 \mathrm{~mm})$ correlated significantly with predicted peaks in hatching $(P<0.0001)$, based on the published relationship between incubation temperature and time to hatch (Frank and Leggett, 1981b). Similarly, peaks in recently hatched larvae correlated significantly with predicted peaks in hatching $(P<0.0001)$ at two beach sites within the study area in 2004.

\section{Habitat Classification of Demersal Capelin Spawning Sites}

Three acoustic classes were generated for six of the demersal spawning sites (sites 1-3 and 5-8, Fig. 1). The most northerly site (site 4, Fig. 1) only generated a single acoustic seabed class whereas the non-spawning site generated two classes. The sites with three acoustic classes fell into three groupings. Two sites were dominated by one of the three acoustic classes which occupied $72 \%$ and $83 \%$ of the surveyed areas. Three sites were dominated by two of the three acoustic classes; the dominant class 


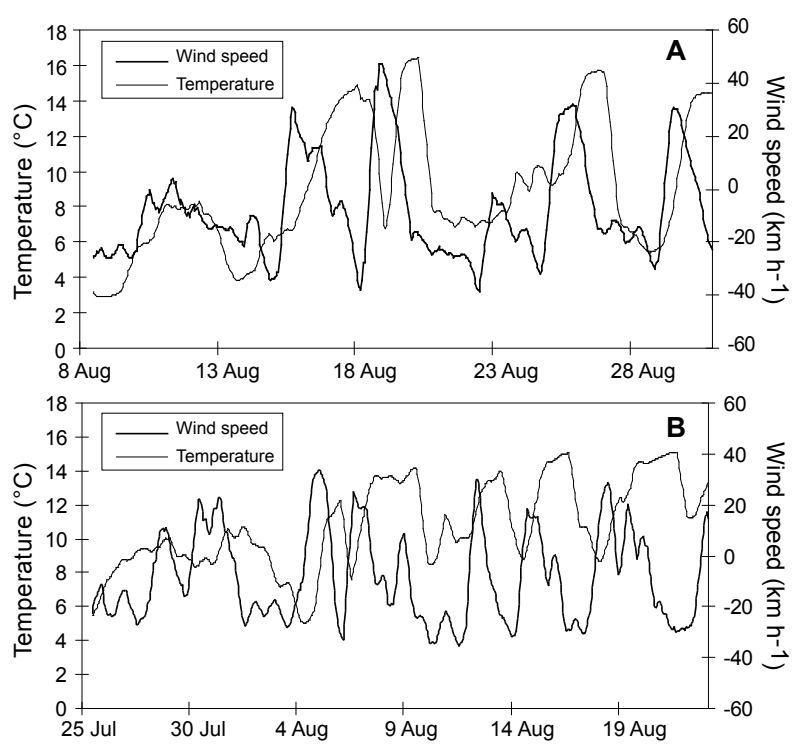

Fig. 3. Smoothed (12-h running average) wind (Pool's Island) and bottom water temperature time series data at capelin demersal spawning site 6 on the northeast Newfoundland coast in (A) 2004 and (B) 2005.

occupied $53-58 \%$ of the survey area, whereas the minor class occupied $33-40 \%$ of the area. Finally, one site had a relatively even distribution of acoustic classes throughout the area, ranging from $24-42 \%$ within the surveyed area. There was no apparent geographic distribution of the sites based on the spatial distributions of unsupervised acoustic classes. Supervised classification of the spawning sites was based on a training data set that consisted of four seabed categories: fine sand, gravel, cobble/boulder and macroalgae (Fig. 4). The gravel category represents the point locations identified as capelin spawning sites and consisted of medium sand to coarse pebble, with a median grain size diameter range of 0.24-26.0 $\mathrm{mm}(n=37)$. The non-spawning habitat consisted of fine sand, with a median grain size diameter range of 0.13 $0.25 \mathrm{~mm}(n=11)$. Cobble/boulder as well as outcrops of bedrock and macroalgae (Laminaria sp., Agarum cribosum) categories were dominant seabed types identified in the video data and were associated with some of the unsupervised acoustic classes. For $1 \mathrm{~km}^{2}$ areas centered around each of the nine sites the proportion of the seabed identified as suitable capelin spawning habitat ranged from $25-61 \%$ and overall averaged $42 \%$.

\section{Diel Vertical Migration of Zooplankton and Capelin}

Three distinct thermal habitats were identified in the water column: the warm mixed surface layer $\left(0-60 \mathrm{~m} ; 0-17^{\circ} \mathrm{C}\right)$, the cold intermediate layer (CIL; $60-180 \mathrm{~m} ;<0^{\circ} \mathrm{C}$ ) and the warm bottom layer

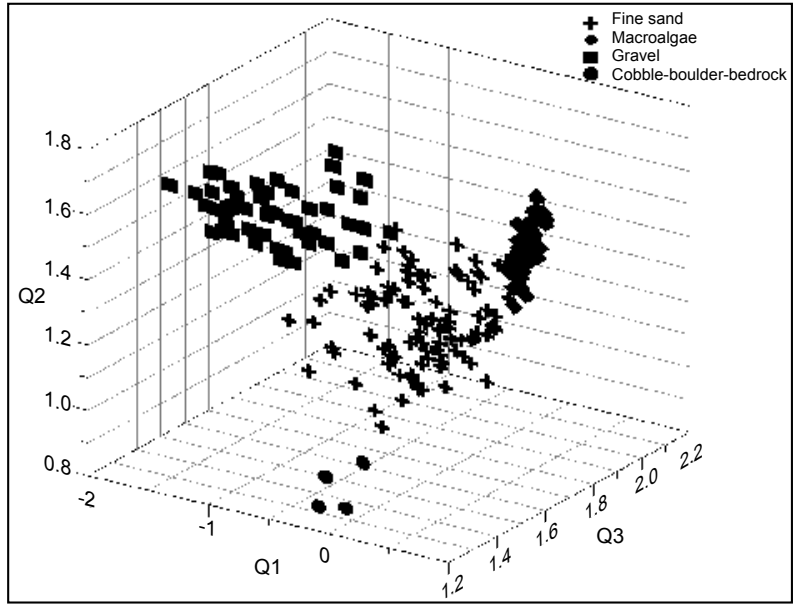

Fig. 4. Three dimensional scatter plot of the supervised classes. Q1, Q2, and Q3 represent principal components of the echo signal as determined by PCA statistical analysis (QTC, 2004). Class 1-Crosses = fine sand; class 2 -Diamonds = macroalgae; class 3-Squares $=$ gravel (spawning substrate); class 4-Circles = cobble, boulder, bedrock.

$\left(>180 \mathrm{~m} ; 0-4^{\circ} \mathrm{C}\right)$. Light penetration was restricted to the top $50 \mathrm{~m}$ during daylight and was consistently low throughout the water column during dark. Acoustic backscatter data revealed a distinct movement of zooplankton and capelin into warm surface waters during dusk twilight ( 20:00-21:00 Newfoundland Standard Time, NST) and then back down toward the seabed during dawn twilight ( 04:00-06:00 NST). Two distinct groups of zooplankton migrators were observed, one migrating down to $\sim 250 \mathrm{~m}$ of water and the other migrating just within the upper $100 \mathrm{~m}$ (Fig. 5).

The response to environmental cues differed between the two groups of migrating zooplankton. A high correlation was found between cloud opacity and the timing of the deep migration. Zooplankton migrators spent 20-30 min longer at the surface during dawn and dusk on overcast days than on clear days $(P<0.05$ for more than half of the moorings, and $P<0.2$ for nearly all of the moorings), with dawn descent typically showing a higher statistical significance. Timing of the shallow migrators was less sharply defined, and the correlation to cloud opacity was less apparent.

Temperatures appeared to influence both groups of zooplankton DVM on two time scales. During periods of surface warming in the summer, isotherms may deepen abruptly and migrators may follow them. These are isolated events that are uncommon but easily identifiable in 


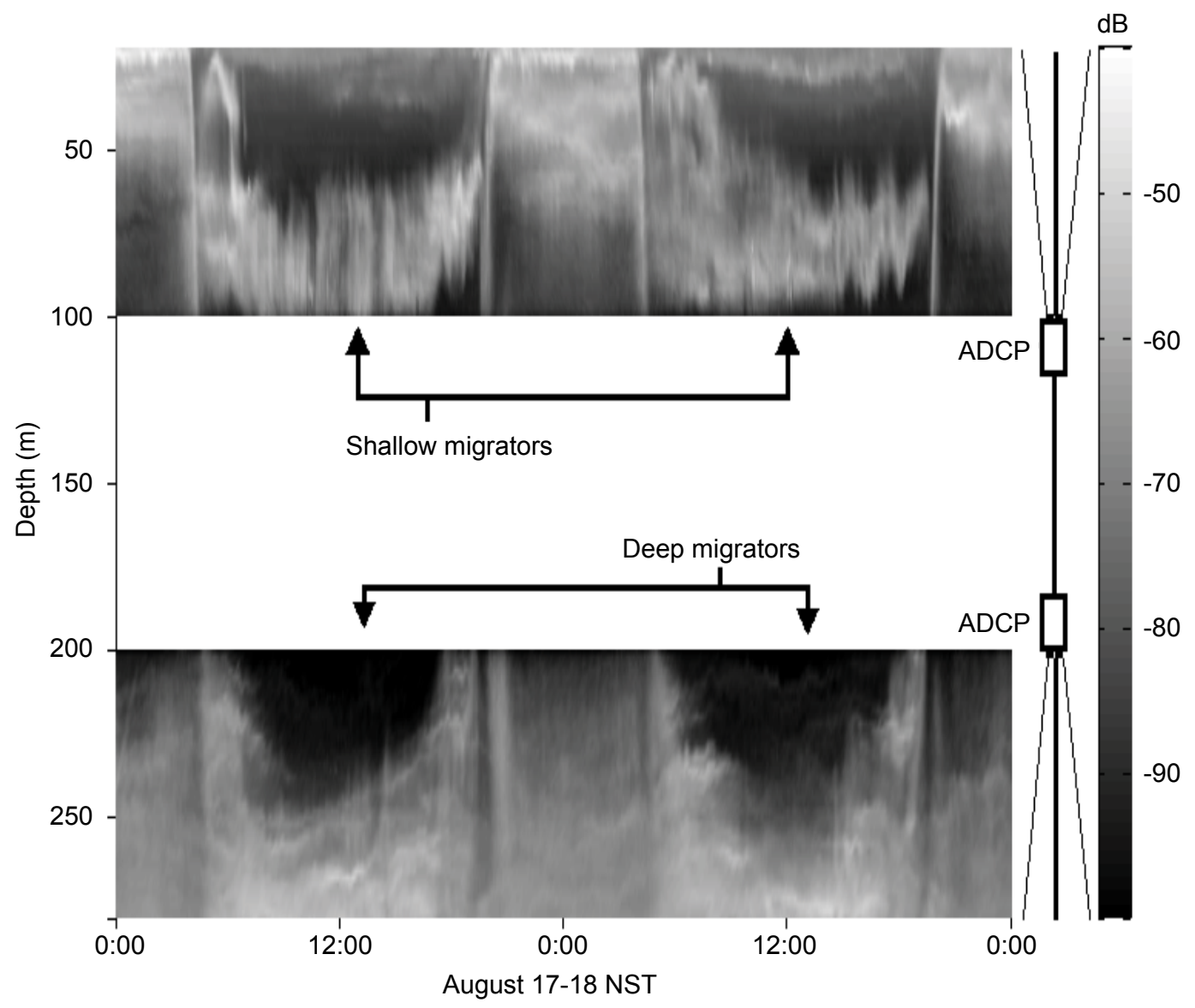

Fig. 5. A two day sample of backscatter data from the two Acoustic Doppler Current Profilers moored in 2005, on the Funk Island Bank, showing the presence of two groups of zooplankton migrators (-65-75 dB range), one migrating within the top $100 \mathrm{~m}$ and one migrating to $\sim 250 \mathrm{~m}$. Total water depth is $298 \mathrm{~m}$. Time is shown in Newfoundland Standard Time.

both shallow and deep migrators. There is also a strong low-frequency response to changing temperatures, with a high coherence between zooplankton migration at middepths and isotherm depths at time scales of 20 days or longer (Record and deYoung, 2006).

For the shallow migrators, there is a secondary spike in coherence showing a migration response to isotherm depths at time scales of 3-5 d. A temperature-depth preference is also seen in shallow migrators, showing a daytime presence in shallower waters $(20-50 \mathrm{~m})$ at temperatures $<5^{\circ} \mathrm{C}$ and a pronounced absence at these depths at higher temperatures $\left(5-17^{\circ} \mathrm{C}\right)$. These behaviours are not apparent for the deep migrators.

Capelin size appeared to play a role in the depth of their diel vertical migration, with capelin $<120 \mathrm{~mm}$ migrating with small zooplankton from $0-100 \mathrm{~m}$ and capelin $>120 \mathrm{~mm}$ migrating with larger zooplankton from $0-300 \mathrm{~m}$. When seabird diets consisted primarily of post-spawning capelin (murres: 1998; gannets: 2003), presumably captured at deep (>100 m) off-shore staging areas (Davoren et al., 2006), foraging activities of birds peaked at dawn and dusk (Figs. 6b and 7a). Alternately, when seabird diets consisted of a higher percentage of spawning capelin in 1999, presumably captured at shallow $(<40 \mathrm{~m})$ inshore demersal spawning sites, foraging activity was higher during mid-day (Figs. 6a and 7b).

\section{Seabirds Diet and Capelin Availability}

Murre prey deliveries changed from equal proportions of small ( $49 \%$ by number) and large capelin ( $49 \%$ by number) in 2004 to predominately large capelin ( $63 \%$ by number) in 2005 . The prey deliveries of puffins changed from sandlance ( $94 \%$ by frequency) in 2004 to primarily large capelin ( $83 \%$ by frequency) in 2005 . These dietary shifts corresponded to significant declines in the densities of large capelin (mean \pm SE; 2004: 


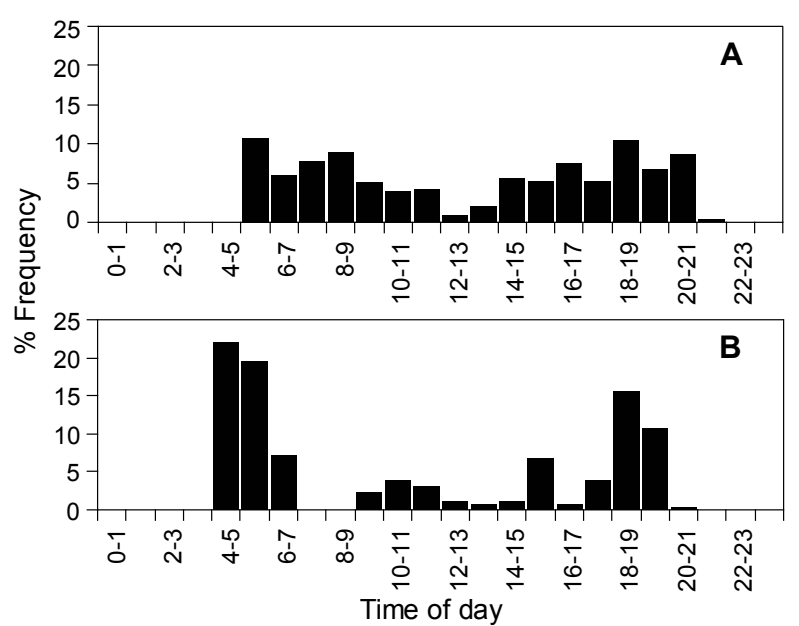

Fig. 6. Diel rhythm in diving activity of Northern Gannets rearing chicks at Funk Island with attached temperature-depth recorders in (A) 1999 ( $n=11$ individuals) and (B) 2003 ( $n=11$ individuals).
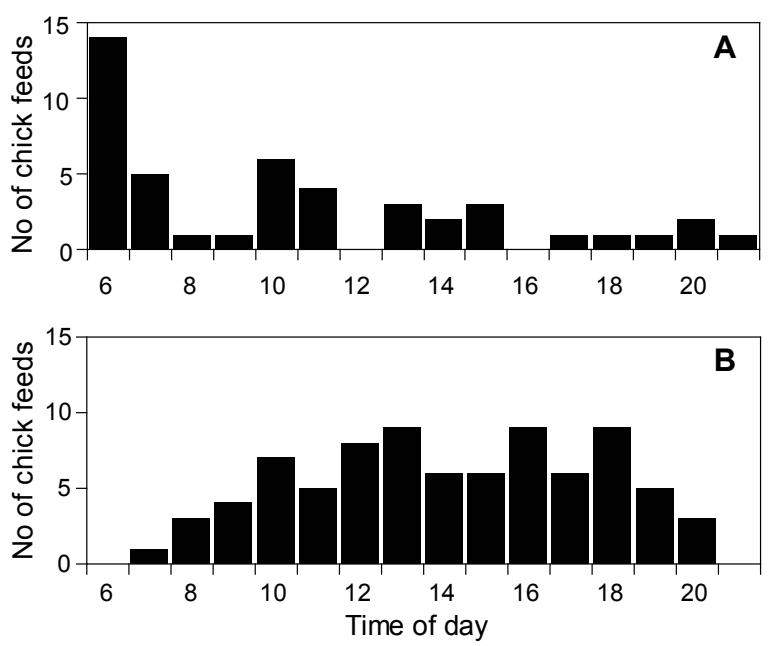

Fig. 7. The number of parental fish deliveries to chicks at nests of Common Murres at Funk Island throughout daylight in (A) 1998 ( $n=22$ nests) and (B) $1999(n=$ 32 nests).

$7022.6 \pm 3996.0$ fish km-2; 2005: $129.7 \pm 45.2$ fish km-2; $G=11.3, \mathrm{df}=92, P<0.001)$ and sandlance during the meso-scale survey (2004: $723.4 \pm 453.0$ fish km $\mathrm{km}^{-2} ; 2005$ : $7.9 \pm 3.4$ fish $\left.\mathrm{km}^{-2} ; G=18.9, \mathrm{df}=92, P<0.001\right)$. Murres' preference for large capelin relative to small capelin increased in 2005 when the availability of this prey declined (2004: $\alpha=1.9 ; 2005: \alpha=46.4)$. This response is consistent with negative prey switching and describes the situation in which a predator increases its relative preference for a given prey as the relative density decreases. Sandlance was the preferred prey for puffins in both years relative to "goop" (2004: $\alpha=17 ; 2005: \alpha=32)$ and in 2005 relative to capelin $>100 \mathrm{~mm}(\alpha=2.1)$; however, the preference for sandlance was weaker in 2005 when sandlance availability declined and large capelin dominated prey deliveries.

Estimates of foraging effort derived from the distances that birds traveled from the colony to foraging sites suggested that birds worked harder in 2005 relative to 2004 when the availability of preferred prey declined (Fig. 8). Kolmogorov-Smirnov tests indicated that during 2005 commuting distances were significantly farther for murres (mean; 2004: $46.5 \mathrm{~km}$; 2005: $63.1 \mathrm{~km}$; $\left.D_{\max }=0.02, P<0.001\right)$ and puffins (mean; 2004: 44.1 $\left.\mathrm{km} ; 2005: 59.3 \mathrm{~km} ; D_{\max }=0.05, P<0.01\right)$. Murre fledglings were significantly lighter at a given wing length in 2005 (mean \pm SE; 2004: $215.0 \pm 3.9 \mathrm{~g} ; 2005: 203.0$ $\left.\pm 4.6 \mathrm{~g} ; F_{1,68}=4.1, P=0.047\right)$, whereas puffin chicks exhibited no inter-annual differences (2004: $277.9 \pm 7.3$; 2005: $258.8 \pm 5.9 \mathrm{~g} ; P>0.05)$. This suggests that parental murres were unable to compensate for the declines in availability of capelin but that prey switching was a viable strategy for puffins.

\section{Modeling Seabird-Capelin Interactions}

Murre diet was composed almost exclusively of capelin, with the contribution of other prey being almost negligible except in 1995 when other prey accounted for $30 \%$ (by number) of the diet (Fig. 9). We schematically characterized the prey field in terms of the abundance of small $(100-140 \mathrm{~mm})$ and large $(>140 \mathrm{~mm})$ capelin as being either in high (1997, 1998 and 2004) or low (1995, 1996, 1999 and 2005) abundance (Fig. 10). One pattern that emerges from a simple comparison between the diet data and capelin availability is that in years of high capelin abundance, the consumption of small and large capelin was not significantly different, while larger capelin were taken in years when suitable capelin abundance was low (Figs. 9 and 10).

Both models described the diet well including the empirical pattern indicated above. The best fit was obtained using the ecological model $(\triangle \mathrm{AICc}=12.5)$, whose behavior was very satisfactory. This model captured most of the characteristics of the time series, some years showing high and others low contrast between the number of small and large capelin delivered to the chicks (Fig. 9). The number of capelin consumed was very well estimated throughout the study period, with the highest discrepancy between the observed and predicted diet of less than $10 \%$ by number in 1999 . 


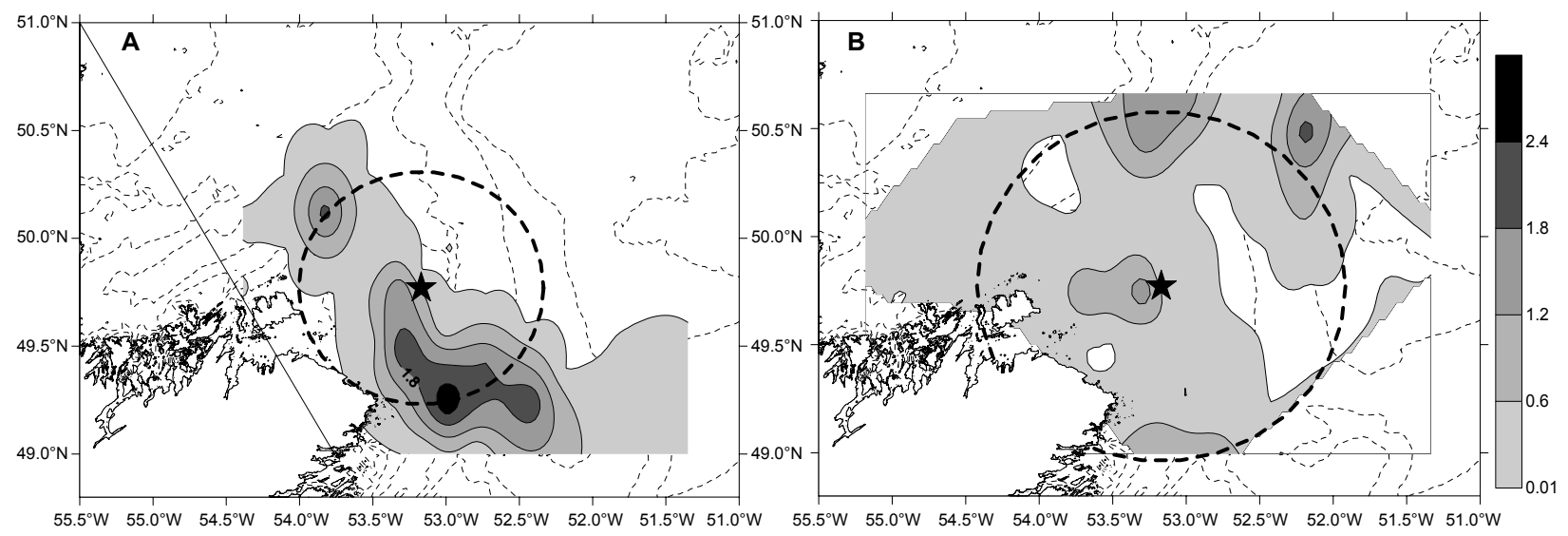

Fig. 8. Capelin ( $>100 \mathrm{~mm}$ ) density (defined as volumetric density $\log _{10} \mathrm{~kg} \mathrm{~m}^{-3}$, calculated as the total number (LN) per species divided by volume of water filtered per trawl) in (A) 2004 and (B) 2005. Circles indicate maximum travel distances, defined as the greatest distance over which $75 \%$ of all birds traveled from Funk Island in 2004 and 2005 as indicated by observations of birds on the water.

\section{Discussion}

This ecosystem-level study provided insight into the mechanisms underlying recent changes in capelin biology and behaviour in the Northwest Atlantic and their potential impacts on top predators and the wider marine community. Specifically, this research increased our understanding of the bio-physical factors that underlie vertical movement patterns in the water column and spawning habitat selection as well as the influence of these behaviours on upper trophic levels. It also revealed the ways in which capelin functions as an ecological link between the lower and upper components of the food web.

Through this research, an acoustic seabed classification system for suitable demersal spawning substrate was quantified (Rose-Taylor, MS 2006). This classification system revealed that the study area may be comprised of a high proportion of suitable habitat for demersal spawning of capelin. Further research is ongoing to develop a habitat suitability model for demersal capelin spawning by combining this classification system with other physical datasets (e.g. bathymetry, temperature) and multi-beam data to determine the spatial extent and locations of potential demersal spawning sites in coastal Newfoundland. Comparing this with spatial extent of known beach spawning will aid the resolution of the relative contribution of demersal versus beach spawning to recruitment in the future.

Demersal spawning is a viable reproductive mode in coastal Newfoundland. Although increasing egg deposition at demersal sites relative to beach sites was generally associated with warmer water/air temperatures, consistent trends in the influence of temperature on site use were unclear (Penton, MS 2006). Owing to these patterns, the spatial and temporal separation of reproductive events between habitats, different selection pressures in each habitat, and the divergent larval emergence strategies, we hypothesize that capelin do not simply select spawning habitat based on environmental conditions (Templeman, 1948), but instead may be obligate beach or demersal spawners (i.e. potentially different subpopulations), contrary to previous hypotheses (Dodson et al., 1991). Work to elucidate capelin genetic stock structure is ongoing through the application of molecular genetic tools (i.e. microsatellite loci) and other novel tools (i.e. otolith microstructure). This will help us assess if differences in egg development and larval emergence strategies at beach and demersal spawning sites are associated with reproductively isolated sub-populations, with the consequent management implications. Further monitoring of demersal sites will also allow researchers to test the competing hypothesis that capelin will shift from beach to demersal spawning habits with predicted ocean climate warming (Nakashima and Wheeler, 2002), thereby indicating whether capelin can be used as sensitive indicators of climate change.

Zooplankon appeared to maximize time at the surface under darkness, suggesting that zooplankton diel vertical migration is driven to some degree by avoidance of visually orienting predators, such as capelin. Deep $(\sim 250 \mathrm{~m})$ and shallow $(<100 \mathrm{~m})$ migrators were observed (Record, MS 2005). Shallow migrators known to be abundant on the Newfoundland Shelf are primarily copepods, in particular Calanus finmarchicus, and deep migrators known to be abundant are amphipods and euphausiids (Dalley 


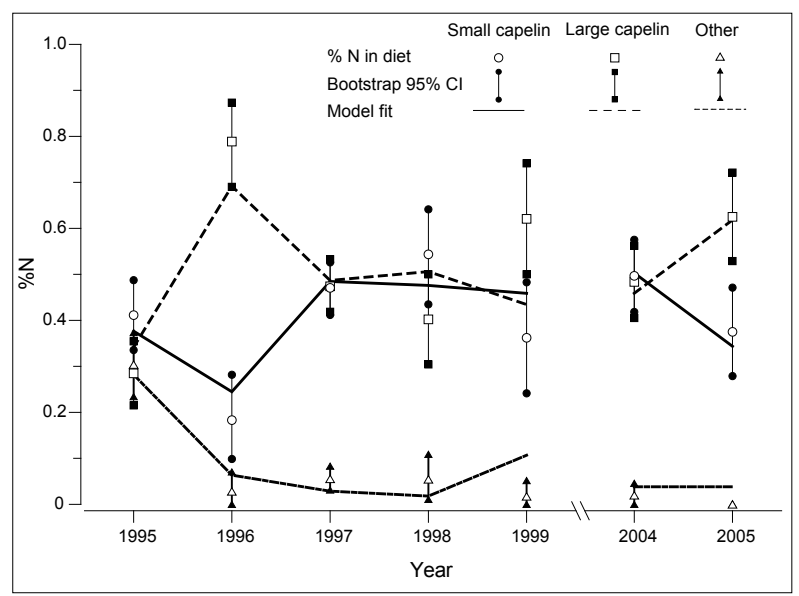

Fig. 9. Fit of the ecological model to the diet data. The circles, squares and triangles are point estimates of the percent by number that small capelin $(100-140 \mathrm{~mm})$, large capelin $(>140 \mathrm{~mm})$ and other prey represent in the diet of common murre, respectively. The bars indicate bootstrap $95 \% \mathrm{CI}$ and the lines represent the model fit.

et al., MS 2001). Capelin underwent similar migratory patterns, with a tendency for larger individuals to migrate with larger zooplankton, while smaller individuals migrate with smaller zooplankton. These vertical movement patterns appeared to influence the foraging activities of their predators. Further investigation of capelin stomach fullness and contents using the samples collected in this study will be key to determining the influence of specific zooplankton species on distributional patterns of capelin. Combining this with monitoring data of zooplankton species composition in the Northwest Atlantic, will increase both our understanding and predictive capacity for changing vertical movement patterns of capelin (Mowbray, 2002) and, thus, distributional patterns in the water column. This information is critical for establishing appropriate timing and design of hydroacoustic surveys to assess capelin biomass (e.g. Neilson et al., 2003), as fish are difficult to detect when they are closely associated with the seabed (Lawson and Rose, 1999). This circumstance could explain divergent capelin biomass estimates among hydroacoustic-derived and spawning-derived indices that were observed in the early 1990s (Carscadden and Nakashima, MS 1997), coincident with the breakdown of regular diel vertical movement patterns (Mowbray, 2002). This could also help explain or predict changes in demographic parameters of air-breathing top predators, especially seabirds, when capelin vertical distributional patterns shift, thereby altering their availability.

We described the diets of two seabird predators with different foraging constraints concurrently with prey

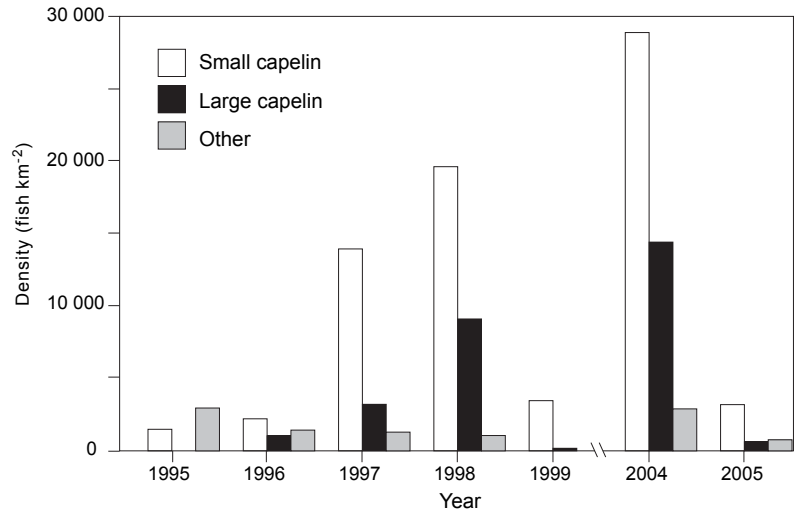

Fig. 10. The availability of prey of common murres around Funk Island, expressed as number of fish per square kilometer. The open bars represent small capelin, the closed bars large capelin and the hatched bars are other prey.

availability. In general, both species flew farther from the colony and delivered larger fish to their chicks in a year when prey availability was low; a response predicted by central place foraging theory (Orians and Pearson, 1979). In particular for the common murre and in years of high prey availability, the consumption of small and large capelin was not significantly different and large capelin were taken in years of low prey availability. Given the high cost of flight for auks, owing to a wing design that is a compromise between underwater and aerial flight (Pennycuick, 1987; Burger, 1991), longer foraging trips would have resulted in higher energy costs and thus greater pressure to deliver larger, more energetically profitable prey to the offspring.

We also found clear evidence that it is feasible to link the diet of common murres and the availability of suitable capelin (i.e. $>100 \mathrm{~mm}$ ). This finding opens the door for developing models that can predict the status of capelin in a suitable size range as a function of the dietary composition of murres, making this source of information potentially useful for the assessment of capelin biomass. Before this can be achieved, however, it will be necessary to link the availability of capelin around Funk Island to the overall capelin stock status. Because there are no estimates of overall capelin stock abundance on the Newfoundland shelf for the period considered in this study, this linkage remains unknown, but the possibilities implied by our results suggest that this path of research is worth pursuing.

This integrated study directly contributes to improved understanding of ecosystem processes and functioning in the Northwest Atlantic, in particular the key role of capelin in food webs. This work also points 
towards new possibilities for future research connecting fish abundance and dynamics and ecosystem characteristics. This could increase our ability to help maintain the long-term productivity of marine ecosystems to sustain fisheries yields and ultimately conserve marine biodiversity.

\section{Acknowledgements}

Principal financial support for this research was provided by a Natural Sciences and Engineering Research Council of Canada (NSERC) Strategic Grant (PI: W.A. Montevecchi; co-PIs: G.K. Davoren, B. deYoung, J.T. Anderson, M. Koen-Alonso). Additional vessel support was provided by Fisheries and Oceans Canada for work aboard the CCGS Wilfred Templeman, along with graduate student stipend support from the Memorial University of Newfoundland and the University of Manitoba. Special thanks to D. Davis, E. Dalley, G. Redmond, E. MacDonald, C. Lang, C. Stevens, F. Mowbray, R. Stead, J. Foley, D. Porter, P. Bazeley, C. Goodyear, A. Hedd, and I. Stenhouse for assistance with field and laboratory work. We are especially indebted to the captain and crew of FV Lady Easton II and CCGS Wilfred Templeman for their support throughout field work. Finally, we sincerely acknowledge the assistance of the residents of communities along the Straight Shore, Newfoundland. Their hospitality and assistance with field work made this project a success.

\section{References}

AGRESTI, A. 2002. Categorical data analysis. Second Edition. Wiley, New York, 710 p.

ANDERSON, J. T., and E. L. DALLEY. 1997. Spawning and year-class strength of northern cod (Gadus morhua) as measured by pelagic juvenile cod surveys, 1991-1994. Can. J. Fish. Aquat. Sci., 54 (Suppl. 1): 158-167.

ANDERSON, J. T., E. L. DALLEY, and R. L. O'DRISCOLL. 2002. Juvenile capelin (Mallotus villosus) off Newfoundland and Labrador in the 1990s. ICES J. Mar. Sci., 59: 917-928. doi:10.1006/jmsc.2002.1241

BAKUN, A. 2006. Wasp-waist populations and marine ecosystem dynamics: Navigating the "predator pit" topographies. Prog. Oceanog., 68: 271-288.

BARRET, R. T. 2002. Atlantic puffin Fratercula arctica and common guillemot Uria aalge chick diet and growth as indicators of fish stocks. Mar. Ecol. Prog. Ser, 230: 275-287.

BERTRAM, D.F., T. GOLUMBIA, G. K. DAVOREN, A. HARFENIST, and J. BROWN. 2002. Short visits reveal consistent patterns of interyear and intercolony variation in seabird nestling diet and performance. Can. J. Zool., 80: $2190-2199$.

BIANCHI, G., H. GISLASON, K. GRAHAM, L. HILL, X. JIN, K. KORANTENG, S. MANICKCHAND-HEILEMAN,
I. PAYÁ, K. SAINSBURY, F. SANCHEZ, and K. ZWANENBURG. 2000. Impact of fishing on size composition and diversity of demersal fish communities. ICES J. Mar. Sci., 57: 558-571. doi:10.1006/jmsc.2000.0727

BIRKHEAD, T. R., and D. N. NETTLESHIP. 1987. Ecological relationships between common murres Uria alge and thick-billed murres Uria lomvia at the Gannet Islands, Labrador. III. Feeding ecology of the young. Can. J. Zool., 65: 1638-1649.

BUREN, A. D., M. KOEN-ALONSO, W.A. MONTEVECCHI, J. T. ANDERSON, B. DEYOUNG, and G. K. DAVOREN. MS 2006. Modeling trophic interactions between parental common murres and capelin off the northeast Newfoundland coast. ICES C.M. Doc., No.2006, L:05, 15 p.

BURGER, A. E. 1991. Maximum diving depths and underwater foraging in alcids and penguins. In: Studies of high-latitude seabirds 1: Behavioural, energetic and oceanographic aspects of seabird feeding ecology. W. A. Montevecchi and A. J. Gaston. (eds.). Can. Wildl. Serv. Occas. Pap., No. 68 , p. 9-15.

BURNHAM, K. P., and D. R. ANDERSON. 2002. Model selection and multi-model inference: a practical information-theoretic approach. Springer, New York, $448 \mathrm{p}$.

CARSCADDEN, J. E., and K. T. FRANK. 2002. Temporal variability in the condition factors of Newfoundland capelin (Mallotus villosus) during the past two decades. ICES J. Mar. Sci., 59: 950-958. doi:10.1006/jmsc.2002.1234

CARSCADDEN, J. E., K. T. FRANK, and D. S. MILLER. 1989. Capelin (Mallotus villosus) spawning on the Southeast Shoal: Influence of physical factors past and present. Can. J. Fish. Aquat. Sci., 46: 1743-1754.

CARSCADDEN, J. E., W. A. MONTEVECCHI, G. K. DAVOREN, B. S. NAKASHIMA. 2002. Trophic relationships among capelin (Mallotus villosus) and marine birds in a changing ecosystem. ICES J. Mar. Sci., 59: 1027-1033. doi:10.1006/jmsc.2002.1235

CARSCADDEN, J. E., and B. S. NAKASHIMA. MS 1997. Abundance and changes in distribution, biology and behavior of capelin in response to cooler waters of the 1990s. In: Forage fishes in marine ecosystems. Proc. Internat. Symp. Forage Fishes in Alaska. Sea Grant Prog. Rep. No. 97-01, p. 457-468.

CURY, P., L. SHANNON, and Y. SHIN. 2003. The functioning of marine ecosystems: a fisheries perspective. In: Responsible fisheries in the marine ecosystem. M. Sinclair and G. Valdimarsson (eds.). Food and Agriculture Organization of the United Nations and CABI Publishing, Rome, p. 103-123.

DALLEY, E. L., J. T. ANDERSON, and D. J. DAVIS. MS 2001. Decadal Time-Series of Invertebrate Zooplankton on the Newfoundland Shelf and Grand Banks 1991-1999. Can. Sci. Advis. Secret., Res. Doc. 2001/110, 1-29. http:// www.dfo-mpo.gc.ca/csas/Csas/publications/ResDocsDocRech/2001/2001_110_e.htm

DAVOREN, G. K. 2007. Effects of gill-net fishing on marine birds in a biological hotspot in the Northwest Atlantic. Cons. Biol., 4: 1032-1045. doi:10.1111/j.15231739.2007.00694.x 
DAVOREN, G. K., J. T. ANDERSON, and W. A. MONTEVECCHI. 2006. Shoal behaviour and maturity relations of spawning capelin Mallotus villosus off the northeast coast of Newfoundland: demersal spawning and diel vertical migratory patterns. Can. J. Fish. Aquat. Sci., 63: 268-284. doi:10.1139/f05-204

DAVOREN, G. K., and W. A. MONTEVECCHI. 2003a. Signals from seabirds indicate changing biology of capelin stocks. Mar. Ecol. Prog. Ser, 258: 253-261.

$2003 \mathrm{~b}$. Consequences of foraging trip duration on provisioning behaviour and fledgling condition of common murres Uria aalge. J. Avian Biol., 34: 44-53. doi:10.1034/j.1600-048X.2003.03008

DODSON, J. J., J. E. CARSCADDEN, L. BERNATCHEZ, and F. COLOMBANI. 1991. Relationship between spawning mode and phylogeographic structure in mitochondrial DNA of North Atlantic capelin Mallotus villosus. Mar. Ecol. Prog. Ser., 76: 103-113.

DRINKWATER, K. F. MS 1996. Atmospheric and oceanographic variability in the northwest Atlantic during the 1980s and early 1990s. J. Northw. Atl. Fish. Sci., 18: 77-97.

2002. A review of the role of climate variability in the decline of Northern cod. In: Fisheries in a changing climate. N.A. McGin (ed.). Am. Fish. Soc. Symp., 32: 99-115.

FAO. 2003. Towards ecosystem-based fisheries management. In: Responsible fisheries in the marine ecosystem. M. Sinclair and G. Valdimarsson (eds.). Food and Agriculture Organization of the United Nations and CABI Publishing, Rome, p. 393-403.

FRANK, K. T., and W. C. LEGGETT. 1981a. Wind regulation of emergence times and early larval survival in capelin (Mallotus villosus). Can. J. Fish. Aquat. Sci., 38: 215-223.

1981b. Prediction of egg development and mortality rates in capelin (Mallotus villosus) from meterological, hydrographic, and biological factors. Can. J. Fish. Aquat. Sci., 38: 1327-1338.

FRANK, K. T., B. PETRI, J. S. CHOI, and W. C. LEGGETT. 2005. Trophic cascades in a formerly cod-dominated ecosystem. Science, 308: 1621-1623. doi:10.1126/science. 1113075

FREITAS, R., S. SILVA, V. QUINTON, A. RODRIGUES, K. RHYNAS, and W. T. COLLINS. 2003. Acoustic seabed classification of marine habitats: studies in the western coastal-shelf area of Portugal. ICES J. Mar. Sci., 60: 599-608. doi:10.1016/S1054-3139(03)00061-4

FRIDGEIRSSON, E. 1976. Observations on spawning behaviour and embryonic development of the Icelandic capelin. Rit Fiskidel. 5: 1-35.

GARCIA, S. M., and I. de LEIVA MORENO. 2003. Global overview of marine fisheries. In: Responsible fisheries in the marine ecosystem. M. Sinclair and G. Valdimarsson (eds.). Food and Agriculture Organization of the United Nations and CABI Publishing, Rome, p. 1-24.

GARTHE, S., S. BENVENUTI, and W. A. MONTEVECCHI. 2003. Temporal patterns of foraging activities of northern gannets Morus bassanus in the north-west Atlantic. Can.
J. Zool., 81: 453-461. doi:10.1139/z03-027

GARTHE, S., W. A. MONTEVECCHI, and G. DAVOREN. 2007. Flight destinations and foraging behaviour of northern gannets (Sula bassana) preying on a small forage fish in a Low Arctic ecosystem. Deep-Sea Res. Part II, 54: 311-320.

HUTCHINGS, J. A. 2000. Collapse and recovery of marine fishes. Nature, 406: 882-885. doi:10.1038/35022565

HUTCHINGS, J. A., and R. A MYERS. 1994. What can be learned from the collapse of renewable resource? Atlantic cod, Gadus morhua, of Newfoundland and Labrador. Can. J. Fish. Aquat. Sci., 51: 2126-2146.

LAVIGNE, D. M. 1996. Ecological interactions between marine mammals, commercial fisheries and their prey: unraveling the tangled web. In: High-latitude seabirds. 4. Trophic relationships and energetics of endotherms in cold ocean systems. W.A. Montevecchi (ed.). Can. Wildl. Ser. Occas. Pap. 91: 59-71.

LAWSON, G. L., and G. A. ROSE. 1999. The importance of detectability to acoustic surveys of semi-demersal fish. ICES J. Mar. Sci., 56: 370-380. doi:10.1006/jmsc.1999.0476

LEGGETT, W. C., K. T. FRANK, and J. E. CARSCADDEN. 1984. Meteorological and hydrographic regulation of year-class strength of capelin (Mallotus villosus). Can. J. Fish. Aquat. Sci., 41: 1193-1201.

LILLY, G. R. 1991. Interannual variability in predation by cod (Gadus morhua) on capelin (Mallotus villosus) and other prey off southern Labrador and northeastern Newfoundland. ICES mar. Sci. Symp., 193: 133-146.

MANGEL, M., and P. S. LEVIN. 2005. Regime, phase and paradigm shifts: making community ecology the basic science for fisheries. Phil. Trans. R. Soc. B, 360: 95-105. doi:10.1098/rstb.2004.1571

MONTEVECCHI, W. A. 2000. Seabirds. In: A mass balance model of the Newfoundland-Labrador Shelf. A. Bundy, G. R. Lilly and P. A. Shelton (eds.). Can. Tech. Rep.Fish. Aquat. Sci., 2310: 15-18.

MONTEVECCHI, W. A., and R. A. MYERS. 1996. Dietary changes of seabirds reflect shifts in pelagic food webs. Sarsia, 80: 313-322.

1997. Centurial and decadal oceanographic influences on changes in northern gannet populations and diets: implications for climate change. ICES J. Mar. Sci., 54: 608-614.

MONTEVECCHI, W. A., and L. M. TUCK. MS 1987. Newfoundland Birds: Exploitation, Study, Conservation. Nuttall Ornithological Club, Harvard University, Cambridge USA, $273 \mathrm{p}$.

MOWBRAY, F. K. 2002. Changes in the vertical distribution of capelin (Mallotus villosus) off Newfoundland. ICES J. Mar. Sci., 59: 942-949. doi:10.1006/jmsc.2002.1259

MURDOCH W. W., S. AVERY, and M. E. B. SMYTH. 1975. Switching in predatory fish. Ecology, 56: 1094-1105. doi: $10.2307 / 1936149$

MYERS, R. A., S. A. AKENHEAD, and K. A. DRINKWATER. 1997. The influence of Hudson Bay runoff and ice-melt of the inner Newfoundland Shelf. Atmos.-Ocean, 28: 241-256.

NAKASHIMA, B. S., and J. P. WHEELER. 2002. Capelin 
(Mallotus villosus) spawning behaviour in Newfoundland waters-the interaction between beach and demersal spawning. ICES J. Mar. Sci., 59: 909-916. doi:10.1006/ jmsc.2002.1261

NEILSON, J. D., D. CLARK, G. D. MELVIN, P. PERLEY, and C. STEVENS. 2003. The diel vertical distribution and characteristics of pre-spawning aggregations of pollock (Pollachius virens) as inferred from hydroacoustic observations: the implications for survey design. ICES J. Mar. Sci., 60: 860-871. doi:10.1016/S1054-3139(03)00068-7

ORIANS, G. H., and N. E. PEARSON. 1979. On the theory of central place foraging. In: Analyses of ecological systems. D.J. Horn, R.D. Mitchell and G.R. Stairs (eds.). Ohio State University Press, Ohio, p. 154-177.

PAULY D., V. CHRISTENSEN, S. GUENETTE, T. J. PITCHER, U. R. SUMAILA, C. J. WALTERS, R. WATSON, and D. ZELLER. 2002. Towards sustainability in world fisheries. Nature, 418: 689-695. doi:10.1038/nature01017

PENNYCUICK, C. J. 1987. Flight of seabirds. In: Seabirds: Feeding ecology and role in marine ecosystems. J.P.Croxall (ed.). Cambridge University Press, Cambridge, United Kingdom, p. 43-62.

PENTON, P. MS 2006. Demersal spawning in capelin (Mallotus villosus) on the northeast coast of Newfoundland. M.Sc. Thesis, Zoology, University of Manitoba, Winnipeg, Manitoba, $121 \mathrm{p}$.

PETRAITIS, P. S. 1979. Likelihood measures of niche breadth and overlap. Ecology, 60: 703-710. doi:10.2307/1936607

PETRAITIS, P. S., and S. R. DUDGEON. 2004. Detection of alternative stable states in marine communities. J. Exp. Mar. Biol. Ecol., 300: 343-371. doi:10.1016/ j.jembe.2003.12.026

PRESTON, J. M., and R. L. KIRLIN. 2003. Comment on "Acoustic seabed classification: improved statistical method". Can. J. Fish. Aquat. Sci., 60: 1299-1300. doi:10.1139/f03-131
QTC. 2004. QTC IMPACT TM Acoustic Seabed Classification. User Guide Version 3.40. Questar Tangent, Marine Technology Centre, Sydney, BC, Canada. 153 p.

RECORD, N. MS 2005. Acoustic imaging of diel vertical migration of zooplankton on the Newfoundland Shelf. M.Sc., Thesis, Physics and Physical Oceanography, Memorial University of Newfoundland, St. John's, Newfoundland, $189 \mathrm{p}$.

RECORD, N., and B. DE YOUNG. 2006. Patterns of diel vertical migration of zooplankton in historical acoustic Doppler velocity and backscatter data on the Newfoundland Shelf. Can. J. Fish. Aquat. Sci., 63: 2708-2721. doi:10.1139/F06-157

RICE, J. 1995. Food web theory, marine food webs, and what climate change may do to northern fish populations. In: Climate change and northern fish populations. R.J. Beamish (ed.). Can. Spec. Pub. Fish. Aquat. Sci., 121: 561-568.

ROSE, G. A., and R. L. O’DRISCOLL. 2002. Capelin are good for cod: can the northern stock rebuild without them? ICES J. Mar. Sci., 59: 1018-1026. doi:10.1006/jmsc.2002.1252

ROSE-TAYLOR, C. MS 2006. Acoustic seabed classification of demersal capelin spawning habitats in coastal northeast Newfoundland. M.Sc., Thesis, Geography, Memorial University of Newfoundland, St. John's, Newfoundland, $131 \mathrm{p}$.

TASKER, M. L., P. HOPE JONES, T. DIXON, and B. F. BLAKE. 1984. Counting seabirds at sea from ships: a review of methods employed and a suggestion for a standardized approach. Auk, 101: 567-577.

TEMPLEMAN, W. 1948. The life history of the caplin (Mallotus villosus O.F. Müller) in Newfoundland waters. Bull. Nfld. Gov. Lab., 17: 1-151.

YODZIS, P. 1994. Predator-prey theory and management of multispecies fisheries. Ecol. Appl., 4: 51-58. doi:10.2307/1942114 